\title{
The relationship between endogenous secretory RAGE and cardiac autonomic function in prediabetes
}

\author{
Rumyana Dimova ${ }^{1}$, Nevena Chakarova ${ }^{1}$, Greta Grozeva ${ }^{1}$, and Tsvetalina Tankova ${ }^{1}$ \\ ${ }^{1}$ Medical University of Sofia
}

June 30, 2021

\begin{abstract}
Aims: The putative protective role of esRAGE for cardiac autonomic function (CAF) remain unclear. To address this question, the present study has assessed the relationship of serum AGEs, sRAGE and esRAGE, and tissue AGEs with CAF in a highrisk population without diabetes. Material and methods: Forty eight subjects of mean age $52.7 \pm 11.2$ years and mean BMI $28.4 \pm 6.3 \mathrm{~kg} / \mathrm{m} 2$, divided into 2 groups according to glucose tolerance: 16 with normal glucose tolerance (NGT) and 24 with prediabetes, were enrolled. A standard OGTT was performed. The glucose tolerance was defined according to 2006 WHO criteria. Fasting, 120-min glucose, lipids, creatinine and HbA1c were measured. eGFR was calculated (CKD-EPI). Fasting, 120min insulin (ECLIA method), esRAGE, sRAGE and AGEs (ELISA method) were assessed. HOMA-IR was calculated. Tissue AGEs were assessed by skin autofluorescence (AGE-Reader, DiagnOpticsTM). CAF was evaluated with ANSAR, applying deep breathing, Valsalva and standing. Results: There was a significant decline in CAF in prediabetes in comparison to NGT. Serum and tissue AGEs, sRAGE and esRAGE levels were similar between groups. On the matrix analysis, both sympathetic and parasympathetic activity at baseline and after standing and sympathetic tone during Valsalva were positively related to esRAGE in prediabetes. Multivariate regression analysis showed that esRAGE is an independent contributor to sympathetic, parasympathetic and total autonomic tone in prediabetes accounting for about $28 \%, 34 \%$ and $35 \%$ of their variances, respectively. Conclusion: Our results have demonstrated that CAF is decreased in prediabetes. esRAGE, but not sRAGE, is reciprocally related to $\mathrm{CAF}$, probably opposing the negative effects of glycation.
\end{abstract}

The relationship between endogenous secretory RAGE and cardiac autonomic function in prediabetes

\section{Running title: esRAGE and autonomic function in prediabetes}

Rumyana Dimova*1, Nevena Chakarova $^{1}$, Greta Grozeva ${ }^{1}$, Tsvetalina Tankova ${ }^{1}$

${ }^{1}$ Department of Endocrinology, Medical University Sofia, 2, Zdrave str., Sofia 1431, Bulgaria

*Corresponding author

\section{ADDRESS FOR CORRESPONDENCE}

Rumyana Dimova, MD

Department of Endocrinology

Division of Diabetology

2, Zdrave str., Sofia 1431, Bulgaria

e-mail: dr.roumyana.dimova@gmail.com

phone number: +359887212573 


\begin{abstract}
Aims: The putative protective role of esRAGE for cardiac autonomic function (CAF) remain unclear. To address this question, the present study has assessed the relationship of serum AGEs, sRAGE and esRAGE, and tissue AGEs with CAF in a high-risk population without diabetes.
\end{abstract}

Material and methods: Forty eight subjects of mean age $52.7 \pm 11.2$ years and mean BMI $28.4 \pm 6.3 \mathrm{~kg} / \mathrm{m}^{2}$, divided into 2 groups according to glucose tolerance: 16 with normal glucose tolerance (NGT) and 24 with prediabetes, were enrolled. A standard OGTT was performed. The glucose tolerance was defined according to 2006 WHO criteria. Fasting, 120-min glucose, lipids, creatinine and HbA1c were measured. eGFR was calculated (CKD-EPI). Fasting, 120-min insulin (ECLIA method), esRAGE, sRAGE and AGEs (ELISA method) were assessed. HOMA-IR was calculated. Tissue AGEs were assessed by skin autofluorescence (AGE-Reader, DiagnOpticsTM). CAF was evaluated with ANSAR, applying deep breathing, Valsalva and standing.

Results: There was a significant decline in CAF in prediabetes in comparison to NGT. Serum and tissue AGEs, sRAGE and esRAGE levels were similar between groups. On the matrix analysis, both sympathetic and parasympathetic activity at baseline and after standing and sympathetic tone during Valsalva were positively related to esRAGE in prediabetes. Multivariate regression analysis showed that esRAGE is an independent contributor to sympathetic, parasympathetic and total autonomic tone in prediabetes accounting for about $28 \%, 34 \%$ and $35 \%$ of their variances, respectively.

Conclusion: Our results have demonstrated that CAF is decreased in prediabetes. esRAGE, but not sRAGE, is reciprocally related to $\mathrm{CAF}$, probably opposing the negative effects of glycation.

Key words: endogenous secretory RAGE, cardiac autonomic activity, prediabetes

\title{
What is already known about this topic?
}

1. Glycation is enhanced in the settings of hyperglycemia, even in early stages of dysglycemia, and presents a key pathological mechanism for diabetic neuropathy.

2. There is plasma soluble receptor for AGE comprising two forms - esRAGE and sRAGE, which has been reported to be involved in the prevention and progression of vascular complications and somatic neuropathy.

\section{What does this article add?}

1. The esRAGE concentration, but not sRAGE levels, was found to be inversely related to cardiac autonomic tone.

2. The esRAGE and sRAGE probably exerts different functions in the AGE-RAGE axis signaling.

3. The esRAGE probably serves as a negative feedback loop to oppose the damaging effects of glycation.

\section{Introduction}

Type 2 diabetes is the most prevalent and serious metabolic disease. Hyperglycemia initiates a vicious cycle of intra- and extracellular disturbances resulting in a broad spectrum of chronic micro- and macrovascular complications. Glycation is enhanced in the settings of increased glucose concentrations and presents a key pathological mechanism, significantly contributing to initiate and/or accelerate chronic diabetic complications. The accumulation of advanced glycation end products (AGEs) affects the target tissue structure and leads to a gradual decline in its function by a receptor-mediated process [1]. The receptor for AGEs (RAGE) is a cell surface multi-ligand receptor of the immunoglobulin superfamily expressed in macrophages, endothelial cells and several other cell types [2], including neural tissue [3]. RAGE signaling pathway is involved in the processes of protein turnover, tissue remodeling and inflammation [4-6] through inducing activation of nuclear factor-kB, increasing expression of cytokines and upregulation of adhesion molecules, evoking oxidative stress and neo-intimal proliferation [7-9]. Its significant role in the development and progression of macro- [10] and micro- [11] vascular complications has been demonstrated. The AGE-RAGE axis has been 
shown to be one of the leading mechanisms linking microvascular disturbances and neuropathy [12]. In experimental models, it has been demonstrated [13] that AGEs induce endothelial dysfunction [14] and decrease blood flow to peripheral nerves [15-17]. An abnormal AGEs accumulation in peripheral nerves in diabetes $[18,19]$ exerts a toxic effect on Schwann, neuronal, vascular and mesangial cells [12, 20-23]. In humans, it has been shown that glycation is an important contributor to small-fiber sensory [24-26] and painful [27] neuropathy and diabetic foot $[14,28]$. However, data on cardiac autonomic neuropathy are still conflicting $[29,30]$.

Since AGEs accumulation is not just a consequence of hyperglycemia, but represents cumulative metabolic burden, its impact is likely to exceed the states of hyperglycemia [31]. RAGE ligands include proinflammatory proteins (S100/calgranulins $[8,32]$ and high-mobility group 1 protein [33]) which might be a key factor linking AGE-RAGE axis with insulin resistance [34]. The responses of AGE-RAGE signaling pathway have been observed in nondiabetic high-risk population at early stages of dysglycemia and in the metabolic syndrome [35, 34]. Of note, AGEs-RAGE axis activity has been proven to be involved in human nondiabetic atherosclerosis [6, 36-38].

There is plasma soluble receptor for AGE (sRAGE) comprising two forms - an endogenous secreted isoform, a spliced variant lacking a transmembrane domain (esRAGE) [39], and the extracellular domain of wild-type RAGE cleaved from the cell membrane [40, 41]. It has been suggested that plasma soluble RAGE serves as a decoy for ligands binding to AGE [34] and plays an antagonistic role by competing with the cell surface receptor, thus opposing the AGE-RAGE signal cascade in vivo and in vitro [32, 33, 42]. However, there is some data that the component of sRAGE derived from proteolytic cleavage might be part of the regulatory process $[40,43]$.

The pivotal role of sRAGE and esRAGE for the prevention and progression of vascular complications [44] and somatic neuropathy has already been shown. However, their putative role in cardiac autonomic neuropathy, remains unclear in diabetes and indefinite in the state of prediabetes.

To address this question the present study has evaluated the circulating levels of serum AGEs, sRAGE and esRAGE, and tissue AGEs accumulation in the high-risk population with normal glucose tolerance (NGT) and prediabetes and their relationship with both sympathetic and parasympathetic activity.

We hypothesized that probably serum and tissue AGEs will be negatively, and sRAGE and esRAGE positively correlated with cardiac autonomic activity even at these early stages of dysglycemia.

\section{Material and methods}

\section{Participants}

Forty eight subjects of mean age $52.7 \pm 11.2$ years and mean BMI $28.4 \pm 6.3 \mathrm{~kg} / \mathrm{m}^{2}$ were enrolled. They were divided into 2 groups according to glucose tolerance: 16 with normal glucose tolerance (NGT) and 24 with prediabetes (16 with impaired fasting glucose and 8 with impaired glucose tolerance).

Participants were recruited at the Department of Endocrinology, Division of Diabetology, Medical University of Sofia within an ongoing diabetes screening program. All subjects were informed about the aims of the study and the risks of participating and declared their written informed consent in accordance with the Helsinki Declaration and rules of Good Clinical Practice, as the study was approved by the Ethics Committee of the Medical University, Sofia.

\section{Exclusion criteria}

Subjects with previously diagnosed type 1 or type 2 diabetes or taking any medication for the indication of diabetes; previously diagnosed with arrhythmias or taking any medications for the indication of arrhythmia; taking any medications for the indication of dyslipidemia; with eGFR-EPI $<60 \mathrm{ml} / \mathrm{min} / 1.73 \mathrm{~m}^{2}$; at the age of $<30$ years or $>70$ years; with serious comorbidities, including kidney, liver, cardiovascular disease, thyroid or recent acute illness, were not eligible for the study. 


\section{Anthropometric parameters}

Height $(\mathrm{cm})$ and weight $(\mathrm{kg})$ were measured and BMI was calculated, using the formula: weight $(\mathrm{kg}) / \mathrm{height}$ $(\mathrm{m})^{2}$. Waist circumference was measured twice in the midline between the inferior margin of the $12^{\text {th }}$ rib and the iliac crest in the standing position after exhalation and averaged.

\section{Functional test}

Glucose tolerance was evaluated during a standard oral glucose tolerance test with 75 g anhydrous glucose after an overnight fast, at least 12 hours after the last meal, refraining from smoking, coffee and taking any medication prior to the test. Participants were on a diet regimen with $150 \mathrm{~g}$ of carbohydrate daily during the last 72 hours prior to the test. The test was initiated between 8.00-9.00 a.m. and the participants remained at a resting seated position throughout the test. Blood samples were taken at 0 and 120 minutes relative to glucose ingestion. The glucose tolerance was defined according to $2006 \mathrm{WHO}$ criteria.

\section{Laboratory tests}

Fasting and 120-min postload plasma glucose were measured by a hexokinase enzyme method (Roche Diagnostics).

- Serum lipid parameters (total cholesterol, HDL cholesterol, LDL cholesterol and triglycerides) were measured at fasting by an enzymatic colorimetric method (Roche Diagnostics).

- HbA1c (NGSP certified) was measured in whole blood samples using immunoturbidimetric method (Roche Diagnostics).

- Serum creatinine was measured at fasting by an enzymatic colorimetric method (Roche Diagnostics).

- Estimated Glomerular Filtration Rate (eGFR) was assessed using the CKD-EPI Creatinine Equation.

- Fasting and 120-min postload serum insulin were assessed by ECLIA method (Roche Diagnostics).

- Homeostatic model assessment of insulin resistance (HOMA-IR) was calculated, using the formula: (fasting plasma glucose $\mathrm{x}$ fasting serum insulin) / 22.5 .

- Endogenous secretory receptor for advanced glycation end products (esRAGE) was assessed by ELISA method (HumaReader HS).

- Soluble receptor for advanced glycation end products (sRAGE) was assessed by ELISA method (HumaReader HS).

- Serum advanced glycation end products (AGEs) were assessed by ELISA method (HumaReader HS).

\section{Instrumental examinations}

tissue advanced glycation products (AGEs)

AGEs accumulation was assessed non-invasively measuring the skin autofluorescence of ultraviolet light on the ventral side of the lower arm (AGE-Reader, DiagnOpticsTM).

cardiac autonomic function

Cardiac autonomic nervous system function was evaluated with ANX-3.0 autonomic monitoring system (ANSAR Medical Technologies, Inc., Philadelphia, PA). This is a software that computes both sympathetic and parasympathetic nervous system activity non-invasively, simultanuously and independently applying spectral analysis of respiratory activity with concomitant spectral analysis of heart rate variability. The system uses both "time-domain" and ,frequency-domain" analysis at rest and during standard autonomic tests: Deep breathing challenge, Valsalva challenge, and Stand challenge. The analysis applied in the ANX3.0 method is focused on the low-frequency range of the spectrum fixed between 0.04-0.15 Hz.

The examination of the cardiac autonomic function was performed under standard conditions including - at least 24 hours after the last dose of medications affecting autonomic function - antihypertensives, tricyclic antidepressants and SSRIs, refraining from coffee and smoking at least 12 hours prior to the test, at least 30 minutes after the last meal, in the time interval between $8.00-11.00 \mathrm{am}$.

\section{Statistical analyses}


Statistical analyses of the data was performed by SPSS 21.0 (SPSS, Chicago, USA). Descriptive statistics was used to describe the data in the two groups. The data are expressed as mean \pm standard deviation (SD) and median (percentile $25 \%$ to $75 \%$ ). Logarithmic transformation was used for the data with skewed distribution. One-way analysis of variance (One-way ANOVA) was used for comparison of the groups. Principal component analysis was performed to define a principal component variable for sympathetic, parasympathetic and total autonomic activity at rest and during autonomic tests. Partial correlation test, controlling for age and BMI, was applied to assess the relationship between sympathetic, parasympathetic and total autonomic activity and AGE/RAGE levels. Pearson correlation test was performed for the assessment of the relationship between cardiac autonomic function principal component variables and AGE/RAGE levels and estimated metabolic parameters. Multiple linear regression with stepwise forward method was used for the evaluation of the predictive value of esRAGE levels for sympathetic, parasympathetic and total autonomic activity. A p-value (two tailed) of less than 0.05 was considered statistically significant.

\section{Results}

Main characteristics of the groups are present in Table 1. Between-group differences were observed in age, BMI, waist circumference, plasma glucose levels during OGTT, serum insulin at fasting, HOMA-IR, and most of sympathetic and parasympathetic tone indices. All other parameters, including postload serum insulin, lipid levels, HbA1c, serum creatinine levels, eGFR, serum and tissue AGEs, sRAGE and esRAGE were not significantly different between the groups.

Table 2 provides data on the matrix analysis, including the whole cohort, and a separate analysis of the two subject groups. Both sympathetic and parasympathetic activity parameters at baseline and after standing and sympathetic tone index during Valsalva were positively related to esRAGE levels in the studied cohort and this relationship was consistent with the results in the prediabetes group but failed to achieve significance in the NGT group. sRAGE, serum AGEs and tissue AGEs accumulation showed no association with cardiac autonomic function.

Multivariate regression analyses were performed to estimate whether there was an independent relationship between esRAGE levels and cardiac autonomic function. On the multiple linear regression analyses with stepwise method, after controlling for age and BMI, esRAGE emerged as an independent contributor to sympathetic, parasympathetic and total autonomic tone in prediabetes accounting for about $28 \%, 34 \%$ and $35 \%$ of their variances, respectively (Table 3 ).

No correlation was found between tissue AGEs accumulation, serum AGEs, sRAGE and esRAGE serum levels and estimated metabolic parameters (Suppl. Table 1). Sympathetic, parasympathetic and total autonomic activity component variables showed an inverse correlation with age, HbA1c, LDL cholesterol, total cholesterol, triglycerides and eGFR (Suppl. Table 2).

\section{Discussion}

This study supports the importance of prediabetes as a category of increased risk for the development of cardiac autonomic dysfunction since both sympathetic and parasympathetic tone has been found to be declined in prediabetes in comparison to NGT.

Our results do not show any relationship between serum AGEs and the parameters of cardiac autonomic activity, which is in line with some reported data in type 2 diabetes with short [29] and long [45] duration. Tissue accumulation of the heterogeneous AGEs have also been measured indirectly by skin autofluorescence [46] and the results have been in consistence with the findings for the serum AGEs.

However, most studies in type $1[24,47]$ and type 2 [48] diabetes have uniformly confirmed the key role of glycation in the development and acceleration of diabetic neuropathy. The important role of glycation in the pathophysiology of both diabetic peripheral and autonomic neuropathy has been demonstrated, even before the clinical manifestation of neuropathy [30]. It has been suggested that the peripheral nerve fiber loss in diabetes is partly due to the AGEs accumulation [49]. RAGE has been demonstrated to be expressed in endothelial and Schwann cells of perineural and endoneural vessels [3, 49]. In experimental models AGEs 
even at physiological concentration have been reported to decline the viability of Schwann cells [50] through facilitating of endothelial dysfunction [14], which may affect every component in the peripheral nervous system. The alterations in protein structure mediated directly by AGEs toxic effect or indirectly by AGE/RAGE cascade results firstly in functional (interruption of axonal transport) with consequent structural (the development of atrophy and degeneration) abnormalities in the peripheral nerves $[15,51]$. In summary, the fulcrums of the negative effect of glycation in the nerve tissue are reduced $\mathrm{Na}+\mathrm{K}+$-ATPase [15] and nitric oxide [16, 17] activity, and glycation of collagen and laminin [16] resulting in increased permeability of blood vessels [16], reduced nerve blood flow and hypoxia [17]. The impairment of endothelial cell function caused by AGE/RAGE axis even in prediabetes involves increased activity of NF- $\chi \mathrm{B}$ and activator protein-1, which enhance the expression of vascular cell adhesion molecule-1, tumor necrosis factor and interleukin-6 [52, 53].

These discrepancies are highly likely to be due to the variable role of hyperglycemia for AGEs and RAGE formation at these early stages of impaired glucose homeostasis and the predominant role of some confounding factors - low-grade inflammation, oxidative stress, insulin resistance and metabolic syndrome. RAGE activation is the consequence of both AGEs and different pro-inflammatory molecules, which exert a synergistic effect in the initiation and/or progression of diabetes chronic complications [54]. Therefore, it might be speculated that at these early stages of dysglycemia probably not hyperglycemia, but low-grade inflammation, as a consequence of insulin resistance, is the predominant stimulus for the development of late complications of diabetes.

With regard to sRAGE and esRAGE levels, it has been assumed that they are involved in the negative feedback regulation of RAGE-mediated signaling by blocking the RAGE. Their anti-inflammatory effect and role in the balance between oxidative stress and antioxidant defense have been suggested even in prediabetes [55]. Since data have shown the putative independent beneficial effect of statins and pioglitazone on sRAGE and esRAGE levels [56,57], all screened subjects on lipid lowering treatment were excluded from the analysis in the current study.

Our findings have demonstrated no statistically significant difference in sRAGE and esRAGE levels between the groups with NGT and prediabetes, which is in consistence with some available data [58-60]. However, the predominant data have shown lower levels of sRAGE $[55,61]$ and esRAGE $[55,58,61-63]$ in prediabetes, which is assumed to be linked to a loss of protection against low-grade inflammation in this high-risk population.

On a matrix analysis, both sympathetic and parasympathetic tone have been observed to be positively related to esRAGE, but not to sRAGE, in the studied cohort and in the prediabetes group. These findings support the conception for the protective role of esRAGE in the continuum of glycation process, preventing autonomic nerves from the deleterious effects of AGE/RAGE cascade. esRAGE has been considered a competitive inhibitor of AGE/RAGE signal pathways, since it acts as a decoy receptor for AGEs. Thus, esRAGE exhibits a feedback mechanism, by which inhibits AGE/RAGE cascade [32].

Our cohort consists of subjects with prediabetes and NGT, suggesting that the potential significance of esRAGE for the autonomic power is not confined to diabetes. Moreover, plasma esRAGE levels have been suggested to be more closely associated with early stage of dysglycemia, rather than overt diabetes [6466]. Although an independent association between esRAGE levels and coronary artery disease has been confirmed in high-risk population without diabetes $[67,68]$ and decreased levels of esRAGE have been reported to predict cardiovascular mortality not only in diabetes, but also in prediabetes [69], it is unclear whether sRAGE levels are related to atherosclerosis. Both lower [70] and elevated [71] levels of sRAGE have been reported in subjects with coronary artery disease without diabetes.

Circulating sRAGE isoform seems to be under the control of different mechanism. An alternative splicing has been suggested to generate esRAGE and proteolytic shedding of cell-surface RAGE - to generate sRAGE, which might be the reason for distinct roles of these soluble forms in certain disease conditions. Thereafter, it is of paramount significance to distinguish the exact physiological relevance of both markers. Probably sRAGE and esRAGE are under distinct regulation and independently influence AGE/RAGE axis in different 
manner.

Although the simultaneous evaluation of both sRAGE and esRAGE together with serum and tissue AGEs strengthen the analysis, our results share the limitations of a cross-sectional design with relatively small sample size.

In conclusion, our data have demonstrated that both sympathetic and parasympathetic activities are already declined in prediabetes. The esRAGE concentration, but not sRAGE levels, seems to be inversely related to autonomic tone, probably serving as a negative feedback loop to oppose the damaging effects of glycation. Larger prospective studies are needed to evaluate the causal relationship between autonomic function and circulating esRAGE and sRAGE, and to distinct their individual pathophysiological significances in different clinical settings.

\section{Conflict of interest}

There are no potential conflicts of interest relevant to this article.

\section{Authorship}

R.D., N.C., G.G., and T.T. have made substantial contributions to conception and design of the current study. R.D. and N.C. analyzed the data. R.D. have drafted the manuscript. T.T. have revised it critically. R.D., N.C., G.G., and T.T. have given final approval for the publication.

\section{References}

1. Jakus V, Rietbrock N. Advanced glycation end-products and the progress of diabetic vascular complications. Physiol Res. 2004;53:131-142.

2. Brett J, Schmidt AM, Zou YS, et al. Tissue distribution of the receptor for advanced glycation endproducts (RAGE): Expression in smooth muscle, cardiac myocytes, and neural tissue in addition to vasculature. Am J Pathol 143: 1699-1712, 1993

3. Wada R, Yagihashi S. Role of advanced glycation end products and their receptors in development of diabetic neuropathy. Ann N Y Acad Sci. 2005;1043:598-604.

4. Wendt TM, Tanji N, Guo J, et al. RAGE drives the development of glomerulosclerosis and implicates podocyte activation in the pathogenesis of diabetic nephropathy. Am J Pathol 2003;162:1123 - 37.

5. Zhou Z, Wang K, Penn MS, et al. Receptor for AGE (RAGE) mediates neointimal formation in response to arterial injury. Circulation 2003;107:2238 - 43.

6. Bucciarelli LG, Wendt T, Qu W, Lu Y, Lalla E, Rong LL, Goova MT, Moser B, Kislinger T, Lee DC, Kashyap Y, Stern DM, Schmidt AM. RAGE blockade stabilizes established atherosclerosis in diabetic apolipoprotein E-null mice. Circulation. 2002;106:2827-2835.

7. Schmidt AM, Yan SD, Wautier JL, Stern D. Activation of receptor for advanced glycation end products: a mechanism for chronic vascular dysfunction in diabetic vasculopathy and atherosclerosis. Circ Res. 1999; 84:489-497.

8. Schmidt AM, Yan SD, Yan SF, Stern DM. The biology of the receptor for advanced glycation end products and its ligands. Biochim Biophys Acta. 2000;1498:99 -111.

9. Schmidt AM, Stern DM. Receptor for age (RAGE) is a gene within the major histocompatibility class III region: implications for host response mechanisms in homeostasis and chronic disease. Front Biosci. 2001;6: D1151-D1160.

10. Cipollone F, Iezzi A, Fazia M, et al. The receptor RAGE as a progression factor amplifying arachidonatedependent inflammatory and proteolytic response in human atherosclerotic plaques: role of glycemic control. Circulation 2003;108:1070e7 
11. Shimoike T, Inoguchi T, Umeda F, Nawata H, Kawano K, Ochi H: The meaning of serum levels of advanced glycosylation end products in diabetic nephropathy. Metabolism 49: 1030-1035, 2000

12. Babizhayev, M.A.; Strokov, I.A.; Nosikov, V.V.; Savel'yeva, E.L.; Sitnikov, V.F.; Yegorov, Y.E.; Lankin, V.Z. The role of oxidative stress in diabetic neuropathy: Generation of free radical species in the glycation reaction and gene polymorphisms encoding antioxidant enzymes to genetic susceptibility to diabetic neuropathy in population of type i diabetic patients. Cell Biochem. Biophys. 2015, 71, 1425-1443.

13. Chen AS, Taguchi T, Sugiura M, Wakasugi Y, Kamei A, Wang MW, Miwa I 2004 Pyridoxalaminoguanidine adduct is more effective than aminoguanidine in preventing neuropathy and cataract in diabetic rats. Horm Metab Res 36:183-187

14. Goova MT, Li J, Kislinger T, et al. (2001) Blockade of receptor for advanced glycation end-products restores effective wound healing in diabetic mice. Am. J. Pathol. 159:513-25.

15. Santini SA, Cotroneo P, Marra G, Manto A, Giardina B, Mordente A, Greco AV, Martorana GE, Magnani P, Ghirlanda G. NA+/K+ ATPase impairment and experimental glycation: the role of glucose autoxidation. Free Radic Res. 1996;24: 381-389.

16. Bucala R, Tracey KJ, Cerami A. Advanced glycosylation products quench nitric oxide and mediate defective endothelium- dependent vasodilatation in experimental diabetes. J Clin Invest. 1991;87:432-438.

17. Amore A, Cirina P, Mitola S, Peruzzi L, Gianoglio B, Rabbone I, Sacchetti C, Cerutti F, Grillo C, Coppo R. Nonenzymatically glycated albumin (Amadori adducts) enhances nitric oxide synthase activity and gene expression in endothelial cells. Kidney Int. 1997;51:27-35.

18. Wada R, Nishizawa Y, Yagihashi N, Takeuchi M, Ishikawa Y, Yasumura K, Nakano M, Yagihashi S (2001) Effects of OPB-9195, anti-glycation agent, on experimental diabetic neuropathy. Eur J Clin Invest $31,513-520$.

19. Sugimoto K, Nishizawa Y, Horiuchi S, Yagihashi S. Localization in human diabetic peripheral nerve of N(epsilon)-carboxymethyllysine-protein adducts, an advanced glycation endproduct. Diabetologia 1997;40:1380-1387

20. Sekido H, Suzuki T, Jomori T, Takeuchi M, Yabe-Nishimura C, Yagihashi S (2004) Reduced cell replication and induction of apoptosis by advanced glycation end products in rat Schwann cells. Biochem Biophys Res Commun 320, 241-248.

21. Koike T, Kameda Y, Makita Z (2000) Neurotoxicity of advanced glycation end-products for cultured cortical neurons. J Neuropathol Exp Neurol 59, 1094-1105.

22. Yamagishi S, Amano S, InagakiY, Okamoto T,Koga K, Sasaki N, Yamamoto H, Takeuchi M, Makita Z (2002) Advanced glycation end products-induced apoptosis and overexpression of vascular endothelial growth factor in bovine retinal pericytes. Biochem Biophys Res Commun 290, 973-978.

23. Yamagishi S, Inagaki Y, Okamoto T, Amano S, Koga K, Takeuchi M, Makita Z (2002) Advanced glycation end product-induced apoptosis and overexpression of vascular endothelial growth factor and monocyte chemoattractant protein-1 in human-cultured mesangial cells. J Biol Chem 277, 20309-20315.

24. Sveen KA, Karime B, Jorum E et al. Small- and large-fiber neuropathy after 40 years of type 1 diabetes: Associations with glycemic control and advanced protein glycation: The Oslo study. Diabetes Care 2013; 36: $3712-3717$

25. Monnier VM, Sell DR, Strauch C, et al., DCCT Research Group. The association between skin collagen glucosepane and past progression of microvascular and neuropathic complications in type 1 diabetes. J Diabetes Complications 2013;27:141-149

26. Jack M, Wright D. Role of advanced glycation endproducts and glyoxalase I in diabetic peripheral sensory neuropathy. Transl Res. 2012;159:355-365. 
27. Bierhaus A, Fleming T, Stoyanov S, et al. Methylglyoxal modification of Nav1.8 facilitates nociceptive neuron firing and causes hyperalgesia in diabetic neuropathy. Nat Med 2012;18:926-933

28. El-Mesallamy HO, Hamdy NM, Ezzat OA, Reda AM. Levels of soluble advanced glycation end productreceptors and other soluble serum markers as indicators of diabetic neuropathy in the foot. J Investig Med. 2011;59:1233-1238.

29. Hansen CS, Jensen TM, Jensen JS et al. The role of serum methylglyoxal on diabetic peripheral and cardiovascular autonomic neuropathy: the ADDITION Denmark study. Diabetic medicine: A Journal of the British Diabetic Association 2015; 32: 778-785

30. Meerwaldt R, Links TP, Graaff R, Hoogenberg K, Lefrandt JD, Baynes JW, et al.: Increased accumulation of skin advanced glycation end-products precedes and correlates with clinical manifestation of diabetic neuropathy. Diabetologia 2005, 48:1637-1644.

31. Nishikawa T, Edelstein D, Du XL, Yamagishi S, Matsumura T, Kaneda Y, Yorek MA, Beebe D, Oates PJ, Hammes HP, Giardino I, Brownlee M. Normalizing mitochondrial superoxide production blocks three pathways of hyperglycemic damage. Nature. 2000;404:787-790.

32. Yonekura H, Yamamoto Y, Sakurai S, Petrova RG, Abedin MJ, Li H, Yasui K, Takeuchi M, Makita Z, Takasawa S, Okamoto H, Watanabe T, Yamamoto H. Novel splice variants of the receptor for advanced glycation end-products expressed in human vascular endothelial cells and pericytes, and their putative roles in diabetes-induced vascular injury. Biochem J. 2003;370:1097-1099.

33. Scaffidi P, Misteli T, Bianchi ME. Release of chromatin protein HMGB1 by necrotic cells triggers inflammation. Nature. 2002;418:191-195.

34. Sullivan C, Futers T, Barrett J, Hudson B, Freeman M, Grant P. RAGE polymorphisms and the heritability of insulin resistance: the Leeds Family Study. Diabetes Vasc Dis Res. 2005;2.

35. Groener, J.B.; Oikonomou, D.; Cheko, R.; Kender, Z.; Zemva, J.; Kihm, L.; Muckenthaler, M.; Peters, V.; Fleming, T.; Kopf, S.; et al. Methylglyoxal and Advanced Glycation End Products in Patients with Diabetes - What We Know so Far and the Missing Links. Exp. Clin. Endocrinol. Diabetes 2017.

36. Kanauchi M, Tsujimoto N, Hashimoto T. Advanced glycation end products in nondiabetic patients with coronary artery disease. Diabetes Care. 2001;24:1620 -1623.

37. Falcone C, Campo I, Emanuele E, Buzzi MP, Zorzetto M, Sbarsi I, Cuccia M. Relationship between the -374T/A RAGE gene polymorphism and angiographic coronary artery disease. Int J Mol Med. 2004;14:10611064.

38. Sakaguchi T, Yan SF, Yan SD, Belov D, Rong LL, Sousa M, Andrassy M, Marso SP, Duda S, Arnold B, Liliensiek B, Nawroth PP, Stern DM, Schmidt AM, Naka Y. Central role of RAGE-dependent neointimal expansion in arterial restenosis. J Clin Invest. 2003;111:959 -972.

39. Park L, Raman KG, Lee KJ, Lu Y, Ferran LJ Jr, Chow WS, Stern D, Schmidt AM. Suppression of accelerated diabetic atherosclerosis by the soluble receptor for advanced glycation endproducts. Nat Med. 1998;4: 1025-1031.

40. Zhang L, Postina R, Wang Y. Ectodomain shedding of the receptor for advanced glycation end products: a novel therapeutic target for Alzheimer's disease. Cell Mol Life Sci 2009;66:3923-3935

41. Zhang L, Bukulin M, Kojro E, Roth A, Metz VV, Fahrenholz F, Nawroth PP, Bierhaus A, Postina R. Receptor for advanced glycation end products is subjected to protein ectodomain shedding by metalloproteinases. J Biol Chem. 2008;283(51):35507-35516.

42. Hanford LE, Enghild JJ, Valnickova Z, Petersen SV, Schaefer LM, Schaefer TM, Reinhart TA, Oury TD. Purification and characterization of mouse soluble receptor for advanced glycation end products (sRAGE). J Biol Chem. 2004;279:50019 -50024 
43. Raucci A, Cugusi S, Antonelli A, et al. A soluble form of the receptor for advanced glycation endproducts (RAGE) is produced by proteolytic cleavage of the membrane-bound form by the sheddase a disintegrin and metalloprotease 10 (ADAM10). FASEB J 2008;22:3716-3727

44. Colhoun HM, Betteridge DJ, Durrington P, et al. Total soluble and endogenous secretory receptor for advanced glycation end products as predictive biomarkers of coronary heart disease risk in patients with type 2 diabetes: an analysis from the CARDS trial. Diabetes 2011;60:2379e85.

45. Liu C., Xu L., Gao H., Ye J., Huang Y.,Wu M., Xie T., Ni P., Yu X., Cao Y., Lu S.: The association between skin autofluorescence and vascular complications in Chinese patients with diabetic foot ulcer: an observational study done in shanghai. Int. J. Low Extrem Wounds. 14, 28-36 (2015)

46. Meerwaldt R, R. Graaff, P.H. Oomen, T.P. Links, J.J. Jager, N.L. Alderson, S.R. Thorpe, J.W. Baynes, R.O. Gans, A.J. Smit, Simple non-invasive assessment of advanced glycation endproduct accumulation, Diabetologia, 47 (2004) 1324-1330

47. Pop-Busui R, Herman WH, Feldman EL, et al., DCCT/EDIC Research Group. DCCT and EDIC studies in type 1 diabetes: lessons for diabetic neuropathy regarding metabolic memory and natural history. Curr Diab Rep 2010;10:276-282

48. Noordzij M.J., Mulder D.J., Oomen P.H., Brouwer T., Jager J., Castro CabezasM., Lefrandt J.D., Smit A.J.: Skin autofluorescence and risk ofmicro- and macrovascular complications in patients with type 2 diabetes mellitus-a multi-Centre study. Diabet. Med. 29, 1556-1561 (2012)

49. Schmidt AM, Hasu M, Popov D, Zhang JH, Chen J, Yan SD, Brett J, Cao R, Kuwabara K, Costache $\mathrm{G}$, et al. Receptor for advanced glycation end products (AGEs) has a central role in vessel wall interactions and gene activation in response to circulating AGE proteins. Proc Natl Acad Sci U S A. 1994;91:8807-8811.

50. Sato K, Tatsunami R, Yama K, Tampo Y. Glycolaldehyde induces cytotoxicity and increases glutathione and multidrugresistance- associated protein levels in Schwann cells. Biol Pharm Bull. 2013;36:1111-1117.

51. Sima AA, Sugimoto K. Experimental diabetic neuropathy: an update. Diabetologia. 1999;42:773-788.

52. Schmidt AM, Hori O, Chen JX, Li JF, Crandall J, Zhang J, Cao R, Yan SD, Brett J, Stern D. Advanced glycation endproducts interacting with their endothelial receptor induce expression of vascular cell adhesion molecule-1 (VCAM-1) in cultured human endothelial cells and in mice. A potential mechanism for the accelerated vasculopathy of diabetes. J Clin Invest. 1995;96:1395-1403.

53. Uribarri J, Stirban A, Sander D, Cai W, Negrean M, Buenting CE, Koschinsky T, Vlassara H. Single oral challenge by advanced glycation end products acutely impairs endothelial function in diabetic and nondiabetic subjects. Diabetes Care. 2007;30(10):2579-2582.

54. Yan SF, Ramasamy R, Naka Y, Schmidt AM. Glycation, Inflammation, and RAGE. A Scaffold for the Macrovascular Complications of Diabetes and Beyond. Circ Res. 2003;93:1159-1169.

55. Huang M, et al. Correlation of the plasma levels of soluble RAGE and endogenous secretory RAGE with oxidative stress in pre-diabetic patients. Journal of Diabetes and Its Complications 29 (2015) 422-426.

56. Koyama H, S. Tanaka, M. Monden, T. Shoji, T. Morioka, S. Fukumoto, K. Mori, M. Emoto, T. Shoji, M. Fukui, H. Fujii, Y. Nishizawa, M. Inaba, Comparison of effects of pioglitazone and glimepiride on plasma soluble RAGE and RAGE expression in peripheral mononuclear cells in type 2 diabetes: randomized controlled trial (PioRAGE), Atherosclerosis, 234 (2014) 329-334.

57. Tam HL, S.W. Shiu, Y. Wong, W.S. Chow, D.J. Betteridge, K.C. Tan, Effects of atorvastatin on serum soluble receptors for advanced glycation end-products in type 2 diabetes, Atherosclerosis, 209 (2010) 173-177.

58. Di Pino et al. Low Endogenous Secretory Receptor for Advanced Glycation End-Products Levels Are Associated With Inflammation and Carotid Atherosclerosis in Prediabetes J Clin Endocrinol Metab, April 2016, 101(4):1701-1709 
59. Biswas SK, Mohtarin S, Mudi SR, Anwar T, Banu L, Alam SM, Fariduddin M, Arslan MI. Relationship of soluble RAGE with insulin resistance and beta cell function during development of type 2 diabetes mellitus. J Diabetes Res 2015;2015:150325.

60. Biswas SK, et al. Relationship of Soluble RAGE with Insulin Resistance and Beta Cell Function during Development of Type 2 Diabetes Mellitus. Journal of Diabetes Research; 2015, Article ID 150325, 6 pages

61. Huang M, Que Y, Shen X. Correlation of the plasma levels of soluble RAGE and endogenous secretory RAGE with oxidative stress in pre-diabetic patients. J Diabet Complicat 2015;29(3):422e6.

62. Tominaga M, Eguchi H, Manaka H, Igarashi K, Kato T, Sekikawa A. Impaired glucose tolerance is a risk factor for cardiovascular disease, but not impaired fasting glucose. The Funagata Diabetes Study. Diabetes Care. 1999;22:920 -924.

63. Stratton IM, Adler AI, Neil HA, Matthews DR, Manley SE, Cull CA, Hadden D, Turner RC, Holman RR. Association of glycaemia with macrovascular and microvascular complications of type 2 diabetes (UKPDS 35): prospective observational study. Bmj. 2000;321:405- 412.

64. Koyama H, Shoji T, Yokoyama H et al. Plasma Level of Endogenous Secretory RAGE Is Associated With Components of the Metabolic Syndrome and Atherosclerosis Arterioscler Thromb Vasc Biol. 2005;25:25872593

65. Cai W, Sun JF, Liu Y et al. Relationship between serum levels of endogenous secretory RAGE and blood pressure in male nondiabetic patients with obstructive sleep apnea. Journal of Human Hypertension (2015), 1-6.

66. Momma H, Niu K, Kobayashi Y, Huang C, Chujo M, Otomo A et al. Lower serum endogenous secretory receptor for advanced glycation end product level as a risk factor of metabolic syndrome among Japanese adult men: a 2-year longitudinal study. J Clin Endocrinol Metab 2014; 99: 587-593.

67. Falcone C, Emanuele E, D’Angelo A et al. Plasma Levels of Soluble Receptor for Advanced Glycation End Products and Coronary Artery Disease in Nondiabetic Men. Arterioscler Thromb Vasc Biol 2005;25:10321037.

68. Selvin E, Halushka MK, Rawlings AM, et al. sRAGE and risk of diabetes, cardiovascular disease, and death. Diabetes. 2013;62: 2116-2121

69. Malmstedt J, Karvestedt L, Swedenborg J, Brismar K. The receptor for advanced glycation end products and risk of peripheral arterial disease, amputation or death in type 2 diabetes: A population-based cohort study. Cardiovasc Diabetol. 2015;14:93.

70. Mahajan N, Malik N, Bahl A, Dhawan V. Receptor for advanced glycation end products (RAGE) and its inflammatory ligand EN-RAGE in non-diabetic subjects with premature coronary artery disease. Atherosclerosis. 2009; 207:597-602.

71. Nakamura K, Yamagishi SI, Adachi H, Kurita-Nakamura Y, Matsui T, Yoshida T, Sato A, Imaizumi T. Elevation of soluble form of receptor for advanced glycation end products (sRAGE) in diabetic subjects with coronary artery disease. Diabetes Metab Res Rev. 2007;23(5): 368-371.

Table 1. Main characteristics of the groups according to glucose tolerance - normal glucose tolerance (NGT) and prediabetes.

Parameter

Age (years)

BMI $\left(\mathrm{kg} / \mathrm{m}^{2}\right)$

Waist circumference $(\mathrm{cm})$

HbA1c (\%) 


\section{Parameter}

Plasma glucose at fasting $(\mathrm{mmol} / \mathrm{l})$

Plasma glucose postload ( $\mathrm{mmol} / \mathrm{l})$

Insulin at fasting $(\mathrm{uIU} / \mathrm{l})$

Insulin postload ( $\mathrm{uIU} / \mathrm{l})$

HOMA-IR index

Total cholesterol $(\mathrm{mmol} / \mathrm{l})$

LDL cholesterol $(\mathrm{mmol} / \mathrm{l})$

HDL cholesterol males (mmol/l)

HDL cholesterol females ( $\mathrm{mmol} / \mathrm{l})$

Triglycerides $(\mathrm{mmol} / \mathrm{l})$

Serum creatinine (umol/l)

eGFR (CKD-EPI) $\left(\mathrm{ml} / \mathrm{min} / 1.73 \mathrm{~m}^{2}\right)$

tissue AGEs

serum AGEs (pg/ml)

esRAGE $(\mathrm{pg} / \mathrm{ml})$

sRAGE $(\mathrm{ng} / \mathrm{ml})$

LFa activity baseline $\left(\mathrm{bpm}^{2}\right)$

$\mathrm{RFa}$ activity baseline $\left(\mathrm{bpm}^{2}\right)$

Total autonomic activity baseline $\left(\mathrm{bpm}^{2}\right)$

LFa activity deep breathing $\left(\mathrm{bpm}^{2}\right)$

RFa activity deep breathing $\left(\mathrm{bpm}^{2}\right)$

Total autonomic activity deep breathing $\left(\mathrm{bpm}^{2}\right)$

LFa activity Valsalva maneuver $\left(\mathrm{bpm}^{2}\right)$

$\mathrm{RFa}$ activity Valsalva maneuver $\left(\mathrm{bpm}^{2}\right)$

Total autonomic activity Valsalva maneuver $\left(\mathrm{bpm}^{2}\right)$

LFa activity standing $\left(\mathrm{bpm}^{2}\right)$

RFa activity standing $\left(\mathrm{bpm}^{2}\right)$

Total autonomic activity standing $\left(\mathrm{bpm}^{2}\right)$

Data are mean \pm SD or median and IQR. sRAGE - soluble receptor for advanced glycation end products; esRAGE - endo

Table 2. Correlation between sympathetic and parasympathetic activity and tissue and serum AGEs, sRAGE and esRAGE.

\section{Parameter \\ Partial \\ Correla- \\ tion, \\ control- \\ ling for \\ age and \\ BMI}

esRAGE

$\mathbf{r}$

Whole

cohort

$\mathrm{Ln}(\mathrm{LFa}$

compo-

nent

variable)
Whole

cohort

0.43

esRAGE

p r

Whole

cohort

0.008
Ln(serum $\quad$ Ln(serum

AGEs) AGEs)

$\mathbf{r}$

Whole

cohort

$-0.18$ p

Whole

cohort

0.293
Ln(tissue Ln(sRAGE) Ln(sRAGE) AGEs)

$\mathbf{r}$

Whole

cohort

0.12

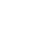

p
Whole
cohort

0.229

Whole

0.229

$\mathbf{r}$

Whole

cohort

$-0.06$
$\operatorname{Ln}($ tiss AGEs)

p

Whole cohort

0.739 


\begin{tabular}{|c|c|c|c|c|c|c|c|c|}
\hline $\begin{array}{l}\text { Parameter } \\
\text { Partial } \\
\text { Correla- } \\
\text { tion, } \\
\text { control- } \\
\text { ling for } \\
\text { age and } \\
\text { BMI }\end{array}$ & esRAGE & esRAGE & $\begin{array}{l}\text { Ln(serum } \\
\text { AGEs) }\end{array}$ & $\begin{array}{l}\text { Ln(serum } \\
\text { AGEs) }\end{array}$ & Ln(sRAGE) & Ln(sRAGE) & $\begin{array}{l}\text { Ln(tissue } \\
\text { AGEs) }\end{array}$ & $\begin{array}{l}\text { Ln(tiss } \\
\text { AGEs) }\end{array}$ \\
\hline $\begin{array}{l}\mathrm{Ln}(\mathrm{RFa} \\
\text { compo- } \\
\text { nent } \\
\text { variable })\end{array}$ & 0.41 & 0.011 & -0.20 & 0.232 & 0.11 & 0.505 & -0.11 & 0.526 \\
\hline $\begin{array}{l}\mathrm{Ln}(\mathrm{LFa}+\mathrm{RFa} \\
\text { compo- } \\
\text { nent } \\
\text { variable })\end{array}$ & 0.43 & 0.008 & -0.19 & 0.265 & 0.15 & 0.372 & -0.08 & 0.634 \\
\hline $\begin{array}{l}\mathrm{Ln}(\mathrm{LFa} \\
\text { baseline })\end{array}$ & 0.42 & 0.009 & -0.07 & 0.700 & 0.14 & 0.421 & -0.19 & 0.251 \\
\hline $\begin{array}{l}\mathrm{Ln}(\mathrm{RFa} \\
\text { baseline })\end{array}$ & 0.29 & 0.080 & -0.09 & 0.610 & 0.31 & 0.068 & -0.19 & 0.253 \\
\hline $\begin{array}{l}\mathrm{Ln}(\mathrm{LFa}+\mathrm{RFa} \\
\text { baseline })\end{array}$ & 0.38 & 0.019 & -0.08 & 0.625 & 0.20 & 0.226 & -0.18 & 0.279 \\
\hline $\begin{array}{l}\mathrm{Ln}(\mathrm{LFa} \\
\text { deep } \\
\text { breathing })\end{array}$ & 0.05 & 0.780 & -0.21 & 0.219 & 0.24 & 0.158 & -0.32 & 0.058 \\
\hline $\begin{array}{l}\mathrm{Ln}(\mathrm{RFa} \\
\text { deep } \\
\text { breathing })\end{array}$ & 0.19 & 0.269 & -0.04 & 0.819 & -0.12 & 0.465 & -0.01 & 0.991 \\
\hline $\begin{array}{l}\mathrm{Ln}(\mathrm{LFa}+\mathrm{RFa} \\
\text { deep } \\
\text { breathing })\end{array}$ & 0.14 & 0.418 & -0.09 & 0.618 & -0.12 & 0.492 & -0.01 & 0.948 \\
\hline $\begin{array}{l}\mathrm{Ln}(\mathrm{LFa} \\
\text { Valsalva) }\end{array}$ & 0.15 & 0.377 & -0.11 & 0.519 & 0.11 & 0.514 & -0.17 & 0.322 \\
\hline $\begin{array}{l}\mathrm{Ln}(\mathrm{RFa} \\
\text { Valsalva) }\end{array}$ & 0.09 & 0.598 & -0.26 & 0.124 & -0.04 & 0.804 & -0.12 & 0.467 \\
\hline $\begin{array}{l}\mathrm{Ln}(\mathrm{LFa}+\mathrm{RFa} \\
\text { Valsalva })\end{array}$ & 0.15 & 0.389 & -0.13 & 0.454 & 0.09 & 0.600 & -0.17 & 0.330 \\
\hline $\begin{array}{l}\mathrm{Ln}(\mathrm{LFa} \\
\text { standing })\end{array}$ & 0.48 & 0.003 & -0.07 & 0.672 & 0.09 & 0.618 & -0.22 & 0.199 \\
\hline $\begin{array}{l}\mathrm{Ln}(\mathrm{RFa} \\
\text { standing })\end{array}$ & 0.36 & 0.028 & -0.13 & 0.429 & 0.21 & 0.204 & -0.38 & 0.021 \\
\hline $\begin{array}{l}\mathrm{Ln}(\mathrm{LFa}+\mathrm{RFa} \\
\text { standing })\end{array}$ & 0.47 & 0.003 & -0.09 & 0.597 & 0.13 & 0.430 & -0.28 & 0.0 .95 \\
\hline $\begin{array}{l}\text { NGT } \\
\text { sub- } \\
\text { group }\end{array}$ & $\begin{array}{l}\text { NGT } \\
\text { sub- } \\
\text { group }\end{array}$ & $\begin{array}{l}\text { NGT } \\
\text { sub- } \\
\text { group }\end{array}$ & $\begin{array}{l}\text { NGT } \\
\text { sub- } \\
\text { group }\end{array}$ & $\begin{array}{l}\text { NGT } \\
\text { sub- } \\
\text { group }\end{array}$ & $\begin{array}{l}\text { NGT } \\
\text { sub- } \\
\text { group }\end{array}$ & $\begin{array}{l}\text { NGT } \\
\text { sub- } \\
\text { group }\end{array}$ & $\begin{array}{l}\text { NGT } \\
\text { sub- } \\
\text { group }\end{array}$ & $\begin{array}{l}\text { NGT } \\
\text { sub- } \\
\text { group }\end{array}$ \\
\hline $\begin{array}{l}\mathrm{Ln}(\mathrm{LFa} \\
\text { compo- } \\
\text { nent } \\
\text { variable })\end{array}$ & 0.07 & 0.821 & -0.21 & 0.504 & -0.18 & 0.568 & -0.09 & 0.791 \\
\hline
\end{tabular}




\begin{tabular}{|c|c|c|c|c|c|c|c|c|}
\hline $\begin{array}{l}\text { Parameter } \\
\text { Partial } \\
\text { Correla- } \\
\text { tion, } \\
\text { control- } \\
\text { ling for } \\
\text { age and } \\
\text { BMI }\end{array}$ & esRAGE & esRAGE & $\begin{array}{l}\text { Ln(serum } \\
\text { AGEs) }\end{array}$ & $\begin{array}{l}\text { Ln(serum } \\
\text { AGEs) }\end{array}$ & Ln(sRAGE) & Ln(sRAGE) & $\begin{array}{l}\text { Ln(tissue } \\
\text { AGEs) }\end{array}$ & $\begin{array}{l}\text { Ln(tiss } \\
\text { AGEs) }\end{array}$ \\
\hline $\begin{array}{l}\mathrm{Ln}(\mathrm{RFa} \\
\text { compo- } \\
\text { nent } \\
\text { variable })\end{array}$ & 0.28 & 0.386 & -0.02 & 0.960 & -0.11 & 0.743 & -0.48 & 0.113 \\
\hline $\begin{array}{l}\mathrm{Ln}(\mathrm{LFa}+\mathrm{RFa} \\
\text { compo- } \\
\text { nent } \\
\text { variable })\end{array}$ & 0.38 & 0.226 & -0.01 & 0.987 & 0.01 & 0.989 & -0.34 & 0.274 \\
\hline $\begin{array}{l}\mathrm{Ln}(\mathrm{LFa} \\
\text { baseline })\end{array}$ & 0.38 & 0.230 & -0.34 & 0.280 & -0.26 & 0.410 & -0.19 & 0.550 \\
\hline $\begin{array}{l}\mathrm{Ln}(\mathrm{RFa} \\
\text { baseline })\end{array}$ & 0.37 & 0.241 & -0.06 & 0.864 & 0.16 & 0.628 & -0.29 & 0.370 \\
\hline $\begin{array}{l}\mathrm{Ln}(\mathrm{LFa}+\mathrm{RFa} \\
\text { baseline })\end{array}$ & 0.46 & 0.135 & -0.19 & 0.553 & -0.17 & 0.597 & -0.05 & 0.871 \\
\hline $\begin{array}{l}\mathrm{Ln}(\mathrm{LFa} \\
\text { deep } \\
\text { breathing })\end{array}$ & 0.16 & 0.625 & -0.03 & 0.933 & 0.50 & 0.097 & -0.76 & 0.004 \\
\hline $\begin{array}{l}\mathrm{Ln}(\mathrm{RFa} \\
\text { deep } \\
\text { breathing })\end{array}$ & 0.36 & 0.252 & -0.22 & 0.490 & -0.40 & 0.196 & -0.37 & 0.240 \\
\hline $\begin{array}{l}\mathrm{Ln}(\mathrm{LFa}+\mathrm{RFa} \\
\text { deep } \\
\text { breathing })\end{array}$ & 0.36 & 0.248 & -0.20 & 0.535 & -0.36 & 0.256 & 0.41 & 0.189 \\
\hline $\begin{array}{l}\text { Ln(LFa } \\
\text { Valsalva) }\end{array}$ & -0.07 & 0.828 & -0.10 & 0.761 & 0.14 & 0.657 & -0.31 & 0.320 \\
\hline $\begin{array}{l}\mathrm{Ln}(\mathrm{RFa} \\
\text { Valsalva) }\end{array}$ & -0.07 & 0.818 & -0.02 & 0.949 & 0.07 & 0.821 & -0.43 & 0.159 \\
\hline $\begin{array}{l}\mathrm{Ln}(\mathrm{LFa}+\mathrm{RFa} \\
\text { Valsalva) }\end{array}$ & -0.07 & 0.820 & -0.09 & 0.775 & 0.14 & 0.665 & -0.33 & 0.292 \\
\hline $\begin{array}{l}\mathrm{Ln}(\mathrm{LFa} \\
\text { standing) }\end{array}$ & 0.55 & 0.062 & -0.61 & 0.036 & 0.01 & 0.993 & -0.51 & 0.094 \\
\hline $\begin{array}{l}\mathrm{Ln}(\mathrm{RFa} \\
\text { standing })\end{array}$ & 0.39 & 0.208 & -0.41 & 0.189 & 0.12 & 0.708 & -0.50 & 0.097 \\
\hline $\begin{array}{l}\mathrm{Ln}(\mathrm{LFa}+\mathrm{RFa} \\
\text { standing })\end{array}$ & 0.54 & 0.066 & -0.58 & 0.047 & 0.02 & 0.940 & 0.53 & 0.073 \\
\hline $\begin{array}{l}\text { Prediabetes } \\
\text { sub- } \\
\text { group }\end{array}$ & $\begin{array}{l}\text { Prediabetes } \\
\text { sub- } \\
\text { group }\end{array}$ & $\begin{array}{l}\text { Prediabetes } \\
\text { sub- } \\
\text { group }\end{array}$ & $\begin{array}{l}\text { Prediabetes } \\
\text { sub- } \\
\text { group }\end{array}$ & $\begin{array}{l}\text { Prediabetes } \\
\text { sub- } \\
\text { group }\end{array}$ & $\begin{array}{l}\text { Prediabetes } \\
\text { sub- } \\
\text { group }\end{array}$ & $\begin{array}{l}\text { Prediabetes } \\
\text { sub- } \\
\text { group }\end{array}$ & $\begin{array}{l}\text { Prediabetes } \\
\text { sub- } \\
\text { group }\end{array}$ & $\begin{array}{l}\text { Predia } \\
\text { sub- } \\
\text { group }\end{array}$ \\
\hline $\begin{array}{l}\mathrm{Ln}(\mathrm{LFa} \\
\text { compo- } \\
\text { nent } \\
\text { variable })\end{array}$ & 0.53 & 0.009 & -0.19 & 0.394 & 0.19 & 0.399 & -0.14 & 0.536 \\
\hline
\end{tabular}




\begin{tabular}{|c|c|c|c|c|c|c|c|c|}
\hline $\begin{array}{l}\text { Parameter } \\
\text { Partial } \\
\text { Correla- } \\
\text { tion, } \\
\text { control- } \\
\text { ling for } \\
\text { age and } \\
\text { BMI }\end{array}$ & esRAGE & esRAGE & $\begin{array}{l}\text { Ln(serum } \\
\text { AGEs) }\end{array}$ & $\begin{array}{l}\text { Ln(serum } \\
\text { AGEs) }\end{array}$ & Ln(sRAGE) & Ln(sRAGE) & $\begin{array}{l}\text { Ln(tissue } \\
\text { AGEs) }\end{array}$ & $\begin{array}{l}\text { Ln(tiss } \\
\text { AGEs) }\end{array}$ \\
\hline $\begin{array}{l}\operatorname{Ln}(\mathrm{RFa} \\
\text { compo- } \\
\text { nent } \\
\text { variable })\end{array}$ & 0.46 & 0.027 & -0.24 & 0.262 & 0.16 & 0.459 & -0.04 & 0.840 \\
\hline $\begin{array}{l}\mathrm{Ln}(\mathrm{LFa}+\mathrm{RFa} \\
\text { compo- } \\
\text { nent } \\
\text { variable })\end{array}$ & 0.49 & 0.018 & -0.24 & 0.280 & 0.19 & 0.391 & -0.05 & 0.834 \\
\hline $\begin{array}{l}\mathrm{Ln}(\mathrm{LFa} \\
\text { baseline })\end{array}$ & 0.46 & 0.028 & -0.04 & 0.841 & 0.21 & 0.348 & -0.29 & 0.180 \\
\hline $\begin{array}{l}\mathrm{Ln}(\mathrm{RFa} \\
\text { baseline })\end{array}$ & 0.24 & 0.280 & -0.18 & 0.410 & 0.34 & 0.115 & -0.15 & 0.498 \\
\hline $\begin{array}{l}\mathrm{Ln}(\mathrm{LFa}+\mathrm{RFa} \\
\text { baseline })\end{array}$ & 0.38 & 0.072 & -0.10 & 0.651 & 0.27 & 0.220 & -0.24 & 0.274 \\
\hline $\begin{array}{l}\mathrm{Ln}(\mathrm{LFa} \\
\text { deep } \\
\text { breathing })\end{array}$ & -0.05 & 0.835 & -0.27 & 0.206 & 0.16 & 0.463 & -0.14 & 0.520 \\
\hline $\begin{array}{l}\mathrm{Ln}(\mathrm{RFa} \\
\text { deep } \\
\text { breathing })\end{array}$ & 0.19 & 0.389 & -0.12 & 0.592 & -0.05 & 0.810 & -0.16 & 0.480 \\
\hline $\begin{array}{l}\mathrm{Ln}(\mathrm{LFa}+\mathrm{RFa} \\
\text { deep } \\
\text { breathing })\end{array}$ & 0.14 & 0.529 & -0.16 & 0.482 & -0.04 & 0.843 & -0.14 & 0.513 \\
\hline $\begin{array}{l}\mathrm{Ln}(\mathrm{LFa} \\
\text { Valsalva) }\end{array}$ & 0.21 & 0.348 & -0.24 & 0.274 & 0.09 & 0.670 & -0.06 & 0.789 \\
\hline $\begin{array}{l}\mathrm{Ln}(\mathrm{RFa} \\
\text { Valsalva })\end{array}$ & 0.09 & 0.691 & -0.34 & 0.116 & -0.08 & 0.712 & -0.02 & 0.922 \\
\hline $\begin{array}{l}\mathrm{Ln}(\mathrm{LFa}+\mathrm{RFa} \\
\text { Valsalva) }\end{array}$ & 0.19 & 0.375 & -0.25 & 0.246 & 0.07 & 0.767 & -0.05 & 0.830 \\
\hline $\begin{array}{l}\mathrm{Ln}(\mathrm{LFa} \\
\text { standing) }\end{array}$ & 0.48 & 0.022 & 0.11 & 0.608 & 0.11 & 0.614 & -0.10 & 0.648 \\
\hline $\begin{array}{l}\mathrm{Ln}(\mathrm{RFa} \\
\text { standing })\end{array}$ & 0.34 & 0.111 & -0.09 & 0.668 & 0.24 & 0.277 & -0.35 & 0.097 \\
\hline $\begin{array}{l}\mathrm{Ln}(\mathrm{LFa}+\mathrm{RFa} \\
\text { standing })\end{array}$ & 0.47 & 0.023 & 0.08 & 0.732 & 0.17 & 0.446 & -0.19 & 0.381 \\
\hline
\end{tabular}




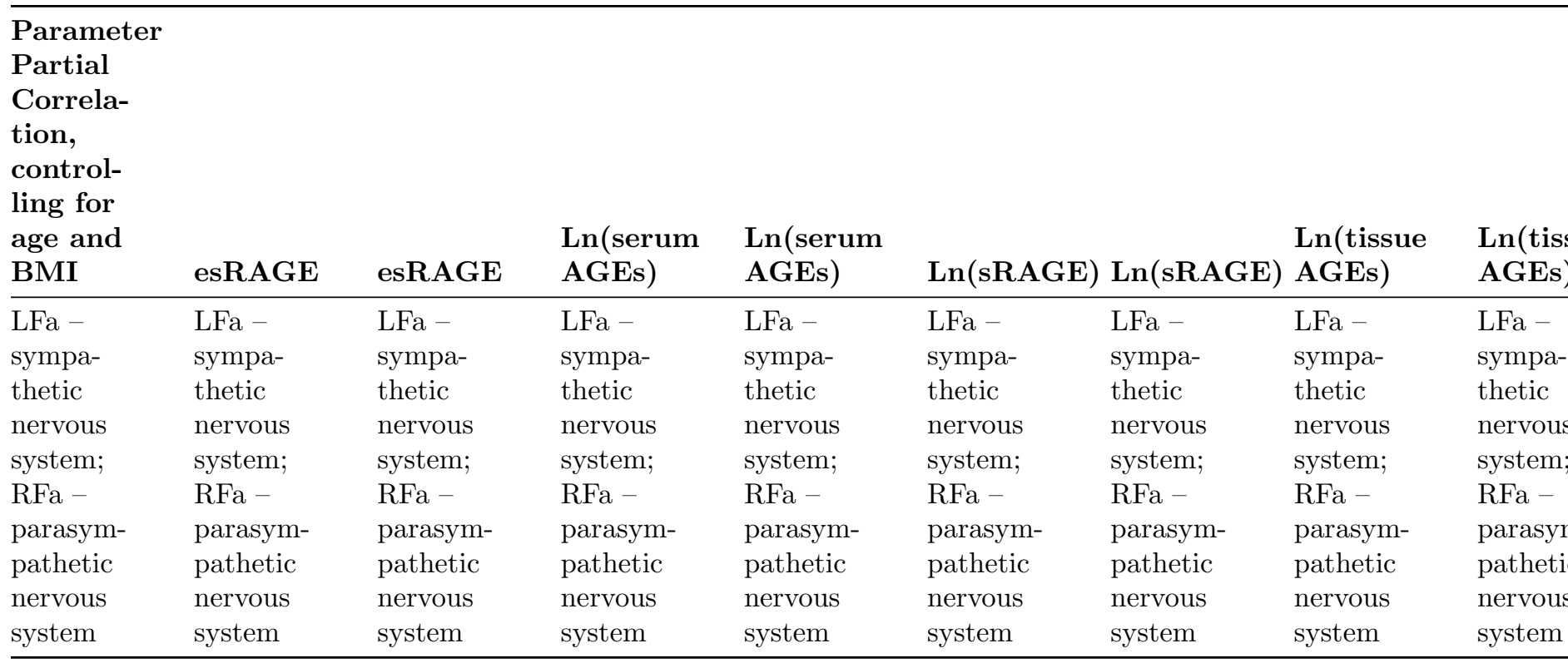

Table 3. Multiple regression analysis for the predictive value of esRAGE for SNS and PSNS activity, controlling for age and BMI.

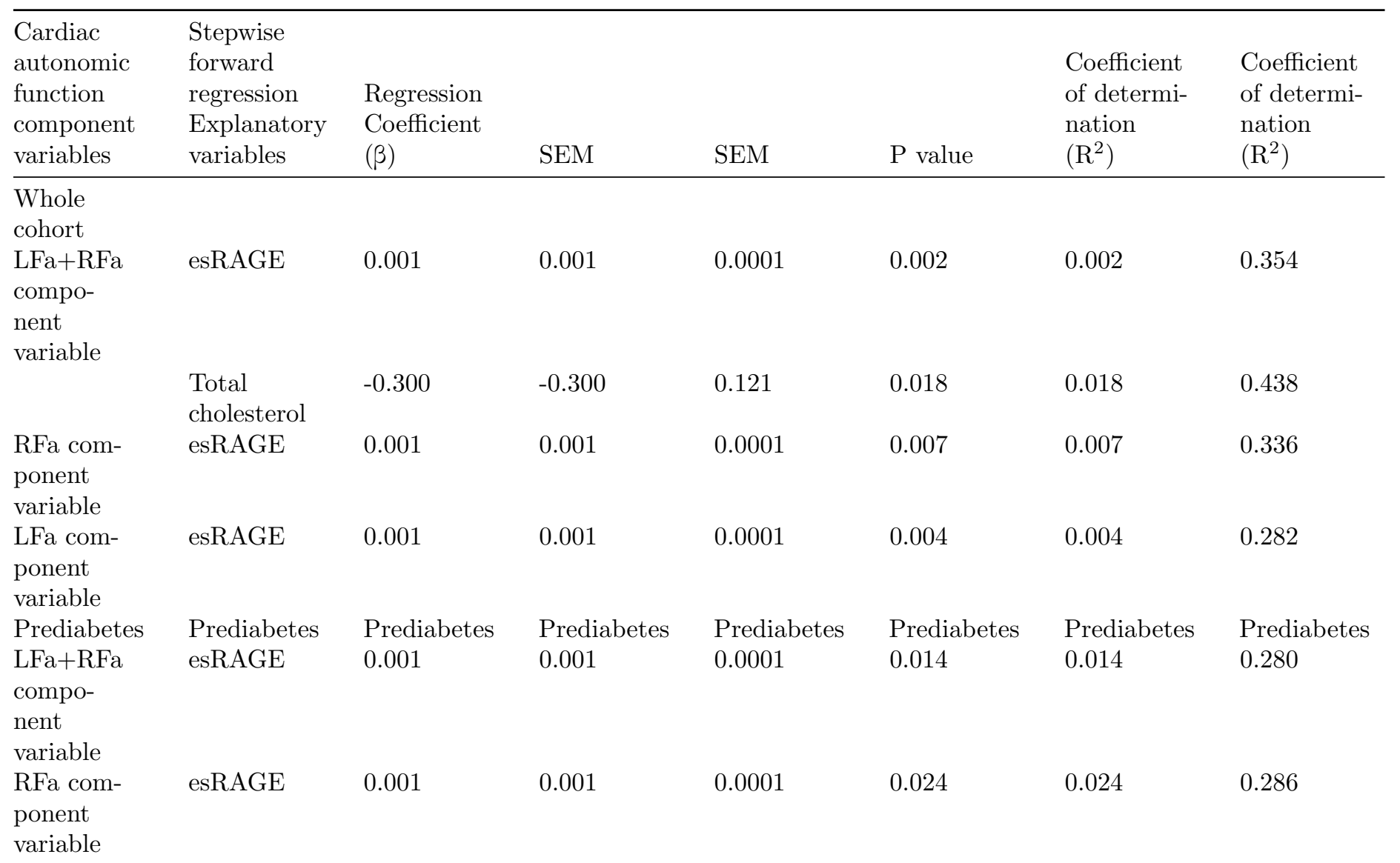




\begin{tabular}{|c|c|c|c|c|c|c|c|}
\hline $\begin{array}{l}\text { Cardiac } \\
\text { autonomic } \\
\text { function } \\
\text { component } \\
\text { variables }\end{array}$ & $\begin{array}{l}\text { Stepwise } \\
\text { forward } \\
\text { regression } \\
\text { Explanatory } \\
\text { variables }\end{array}$ & $\begin{array}{l}\text { Regression } \\
\text { Coefficient } \\
(\beta)\end{array}$ & SEM & SEM & $\mathrm{P}$ value & $\begin{array}{l}\text { Coefficient } \\
\text { of determi- } \\
\text { nation } \\
\left(\mathrm{R}^{2}\right)\end{array}$ & $\begin{array}{l}\text { Coefficient } \\
\text { of determi- } \\
\text { nation } \\
\left(\mathrm{R}^{2}\right)\end{array}$ \\
\hline \multirow{2}{*}{$\begin{array}{l}\text { LFa com- } \\
\text { ponent } \\
\text { variable }\end{array}$} & esRAGE & 0.001 & 0.001 & 0.0001 & 0.007 & 0.007 & 0.282 \\
\hline & $\begin{array}{l}\text { Total } \\
\text { cholesterol }\end{array}$ & -0.447 & -0.447 & 0.200 & 0.036 & 0.036 & 0.410 \\
\hline Variables & Variables & Variables & Variables & Variables & Variables & Variables & Variables \\
\hline entered & entered & entered & entered & entered & entered & entered & entered \\
\hline into the & into the & into the & into the & into the & into the & into the & into the \\
\hline regression & regression & regression & regression & regression & regression & regression & regression \\
\hline analysis: & analysis: & analysis: & analysis: & analysis: & analysis: & analysis: & analysis: \\
\hline esRAGE, & esRAGE, & esRAGE, & esRAGE, & esRAGE, & esRAGE, & esRAGE, & esRAGE, \\
\hline eGFR, & eGFR, & eGFR, & eGFR, & eGFR, & eGFR, & eGFR, & eGFR, \\
\hline triglyc- & triglyc- & triglyc- & triglyc- & triglyc- & triglyc- & triglyc- & triglyc- \\
\hline erides, & erides, & erides, & erides, & erides, & erides, & erides, & erides, \\
\hline total & total & total & total & total & total & total & total \\
\hline choles- & choles- & choles- & choles- & choles- & choles- & choles- & choles- \\
\hline terol, LDL & terol, LDL & terol, LDL & terol, LDL & terol, LDL & terol, LDL & terol, LDL & terol, LDL \\
\hline choles- & choles- & choles- & choles- & choles- & choles- & choles- & choles- \\
\hline terol, & terol, & terol, & terol, & terol, & terol, & terol, & terol, \\
\hline HbA1c. & HbA1c. & HbA1c. & HbA1c. & HbA1c. & HbA1c. & HbA1c. & HbA1c. \\
\hline $\begin{array}{l}\text { Confound- } \\
\text { ing }\end{array}$ & $\begin{array}{l}\text { Confound- } \\
\text { ing }\end{array}$ & $\begin{array}{l}\text { Confound- } \\
\text { ing }\end{array}$ & $\begin{array}{l}\text { Confound- } \\
\text { ing }\end{array}$ & $\begin{array}{l}\text { Confound- } \\
\text { ing }\end{array}$ & $\begin{array}{l}\text { Confound- } \\
\text { ing }\end{array}$ & $\begin{array}{l}\text { Confound- } \\
\text { ing }\end{array}$ & $\begin{array}{l}\text { Confound- } \\
\text { ing }\end{array}$ \\
\hline variables: & variables: & variables: & variables: & variables: & variables: & variables: & variables: \\
\hline age and & age and & age and & age and & age and & age and & age and & age and \\
\hline BMI. LFa & BMI. LFa & BMI. LFa & BMI. LFa & BMI. LFa & BMI. LFa & BMI. LFa & BMI. LFa \\
\hline $\begin{array}{l}\text { - sympa- } \\
\text { thetic }\end{array}$ & $\begin{array}{l}\text { - sympa- } \\
\text { thetic }\end{array}$ & $\begin{array}{l}\text { - sympa- } \\
\text { thetic }\end{array}$ & $\begin{array}{l}\text { - sympa- } \\
\text { thetic }\end{array}$ & $\begin{array}{l}\text { - sympa- } \\
\text { thetic }\end{array}$ & $\begin{array}{l}\text { - sympa- } \\
\text { thetic }\end{array}$ & $\begin{array}{l}\text { - sympa- } \\
\text { thetic }\end{array}$ & $\begin{array}{l}\text { - sympa- } \\
\text { thetic }\end{array}$ \\
\hline nervous & nervous & nervous & nervous & nervous & nervous & nervous & nervous \\
\hline system & system & system & system & system & system & system & system \\
\hline activity; & activity; & activity; & activity; & activity; & activity; & activity; & activity; \\
\hline $\mathrm{RFa}-$ & $\mathrm{RFa}-$ & $\mathrm{RFa}-$ & $\mathrm{RFa}-$ & $\mathrm{RFa}-$ & $\mathrm{RFa}-$ & $\mathrm{RFa}-$ & $\mathrm{RFa}-$ \\
\hline $\begin{array}{l}\text { parasym- } \\
\text { pathetic }\end{array}$ & $\begin{array}{l}\text { parasym- } \\
\text { pathetic }\end{array}$ & $\begin{array}{l}\text { parasym- } \\
\text { pathetic }\end{array}$ & $\begin{array}{l}\text { parasym- } \\
\text { pathetic }\end{array}$ & $\begin{array}{l}\text { parasym- } \\
\text { pathetic }\end{array}$ & $\begin{array}{l}\text { parasym- } \\
\text { pathetic }\end{array}$ & $\begin{array}{l}\text { parasym- } \\
\text { pathetic }\end{array}$ & $\begin{array}{l}\text { parasym- } \\
\text { pathetic }\end{array}$ \\
\hline nervous & nervous & nervous & nervous & nervous & nervous & nervous & nervous \\
\hline system & system & system & system & system & system & system & system \\
\hline activity & activity & activity & activity & activity & activity & activity & activity \\
\hline
\end{tabular}

Supplemental Table 1. Correlations between estimated metabolic parameters and tissue AGEs accumulation, serum AGEs and sRAGE and esRAGE.

\begin{tabular}{|c|c|c|c|c|c|c|c|c|}
\hline \multicolumn{9}{|l|}{$\begin{array}{l}\text { Parameter } \\
\text { Pearson }\end{array}$} \\
\hline & $\mathbf{r}$ & $\mathbf{p}$ & $\mathbf{r}$ & $\mathbf{p}$ & $\mathbf{r}$ & $\mathbf{p}$ & $\mathbf{r}$ & $\mathbf{p}$ \\
\hline
\end{tabular}




\begin{tabular}{|c|c|c|c|c|c|c|c|c|}
\hline $\begin{array}{l}\text { Parameter } \\
\text { Pearson } \\
\text { Correla- } \\
\text { tion } \\
\end{array}$ & esRAGE & esRAGE & $\begin{array}{l}\text { Ln(serum } \\
\text { AGEs) }\end{array}$ & $\begin{array}{l}\text { Ln(serum } \\
\text { AGEs) }\end{array}$ & Ln(sRAGE) & Ln(sRAGE) & $\begin{array}{l}\text { Ln(tissue } \\
\text { AGEs) }\end{array}$ & $\begin{array}{l}\text { Ln(tis: } \\
\text { AGEs) }\end{array}$ \\
\hline $\begin{array}{l}\text { Whole } \\
\text { cohort }\end{array}$ & $\begin{array}{l}\text { Whole } \\
\text { cohort }\end{array}$ & $\begin{array}{l}\text { Whole } \\
\text { cohort }\end{array}$ & $\begin{array}{l}\text { Whole } \\
\text { cohort }\end{array}$ & $\begin{array}{l}\text { Whole } \\
\text { cohort }\end{array}$ & $\begin{array}{l}\text { Whole } \\
\text { cohort }\end{array}$ & $\begin{array}{l}\text { Whole } \\
\text { cohort }\end{array}$ & $\begin{array}{l}\text { Whole } \\
\text { cohort }\end{array}$ & $\begin{array}{l}\text { Whole } \\
\text { cohort }\end{array}$ \\
\hline Age & -0.20 & 0.188 & 0.07 & 0.631 & -0.11 & 0.357 & 0.34 & 0.024 \\
\hline $\begin{array}{l}\text { Waist } \\
\text { circumference }\end{array}$ & 0.17 & 0.255 & 0.19 & 0.203 & 0.01 & 0.999 & -0.13 & 0.390 \\
\hline BMI & 0.06 & 0.688 & 0.20 & 0.184 & 0.03 & 0.862 & -0.13 & 0.389 \\
\hline $\operatorname{Ln}(\mathrm{HbA1c})$ & -0.22 & 0.145 & 0.20 & 0.189 & 0.11 & 0.465 & 0.11 & 0.464 \\
\hline $\begin{array}{l}\text { Plasma } \\
\text { glucose } \\
\text { at } \\
\text { fasting }\end{array}$ & 0.20 & 0.180 & 0.21 & 0.164 & -0.07 & 0.625 & 0.06 & 0.690 \\
\hline $\begin{array}{l}\text { Plasma } \\
\text { glucose } \\
\text { postload }\end{array}$ & 0.16 & 0.291 & 0.24 & 0.121 & 0.06 & 0.709 & -0.02 & 0.912 \\
\hline $\begin{array}{l}\text { Ln(Insulin } \\
\text { at } \\
\text { fasting) }\end{array}$ & 0.04 & 0.793 & 0.18 & 0.245 & -0.11 & 0.466 & -0.25 & 0.108 \\
\hline $\begin{array}{l}\mathrm{Ln} \text { (Insulin } \\
\text { postload) }\end{array}$ & 0.05 & 0.726 & 0.22 & 0.146 & -0.04 & 0.775 & -0.01 & 0.949 \\
\hline $\begin{array}{l}\text { HOMA- } \\
\text { IR } \\
\text { index }\end{array}$ & 0.06 & 0.698 & 0.19 & 0.204 & -0.11 & 0.455 & -0.20 & 0.191 \\
\hline $\begin{array}{l}\text { Total } \\
\text { cholesterol }\end{array}$ & 0.06 & 0.684 & -0.16 & 0.287 & 0.08 & 0.584 & 0.32 & 0.037 \\
\hline $\begin{array}{l}\text { LDL } \\
\text { cholesterol }\end{array}$ & 0.17 & 0.242 & -0.11 & 0.466 & 0.12 & 0.415 & 0.34 & 0.024 \\
\hline $\begin{array}{l}\text { Ln(HDL } \\
\text { cholesterol) }\end{array}$ & -0.15 & 0.315 & -0.02 & 0.895 & 0.01 & 0.987 & 0.22 & 0.148 \\
\hline Ln(Triglycerid & $\operatorname{les} \phi 1$ & 0.998 & -0.04 & 0.783 & -0.02 & 0.891 & -0.19 & 0.227 \\
\hline Ln(eGFR) & -0.16 & 0.303 & -0.15 & 0.335 & 0.09 & 0.568 & -0.16 & 0.295 \\
\hline $\begin{array}{l}\text { NGT } \\
\text { sub- } \\
\text { group }\end{array}$ & $\begin{array}{l}\text { NGT } \\
\text { sub- } \\
\text { group }\end{array}$ & $\begin{array}{l}\text { NGT } \\
\text { sub- } \\
\text { group }\end{array}$ & $\begin{array}{l}\text { NGT } \\
\text { sub- } \\
\text { group }\end{array}$ & $\begin{array}{l}\text { NGT } \\
\text { sub- } \\
\text { group }\end{array}$ & $\begin{array}{l}\text { NGT } \\
\text { sub- } \\
\text { group }\end{array}$ & $\begin{array}{l}\text { NGT } \\
\text { sub- } \\
\text { group }\end{array}$ & & \\
\hline Age & -0.23 & 0.387 & 0.02 & 0.930 & -0.22 & 0.418 & 0.44 & 0.117 \\
\hline $\begin{array}{l}\text { Waist } \\
\text { circumference }\end{array}$ & 0.27 & 0.310 & 0.44 & 0.089 & -0.05 & 0.853 & -0.09 & 0.758 \\
\hline BMI & 0.18 & 0.509 & 0.41 & 0.117 & -0.06 & 0.821 & -0.07 & 0.804 \\
\hline $\operatorname{Ln}(\mathrm{HbA1c})$ & -0.34 & 0.196 & 0.23 & 0.398 & 0.11 & 0.680 & 0.03 & 0.920 \\
\hline $\begin{array}{l}\text { Plasma } \\
\text { glucose } \\
\text { at } \\
\text { fasting }\end{array}$ & 0.03 & 0.902 & 0.35 & 0.180 & -0.44 & 0.092 & -0.10 & 0.747 \\
\hline $\begin{array}{l}\text { Plasma } \\
\text { glucose } \\
\text { postload }\end{array}$ & 0.03 & 0.907 & 0.24 & 0.370 & -0.17 & 0.519 & -0.23 & 0.425 \\
\hline
\end{tabular}




\begin{tabular}{|c|c|c|c|c|c|c|c|c|}
\hline $\begin{array}{l}\text { Parameter } \\
\text { Pearson } \\
\text { Correla- } \\
\text { tion } \\
\end{array}$ & esRAGE & esRAGE & $\begin{array}{l}\text { Ln(serum } \\
\text { AGEs) }\end{array}$ & $\begin{array}{l}\text { Ln(serum } \\
\text { AGEs) }\end{array}$ & Ln(sRAGE) & Ln(sRAGE) & $\begin{array}{l}\text { Ln(tissue } \\
\text { AGEs) }\end{array}$ & $\begin{array}{l}\text { Ln(tiss } \\
\text { AGEs) }\end{array}$ \\
\hline $\begin{array}{l}\text { Insulin } \\
\text { at } \\
\text { fasting }\end{array}$ & 0.07 & 0.804 & 0.20 & 0.467 & -0.10 & 0.723 & 0.04 & 0.886 \\
\hline $\begin{array}{l}\text { Insulin } \\
\text { postload }\end{array}$ & -0.22 & 0.404 & 0.15 & 0.586 & -0.09 & 0.747 & 0.11 & 0.702 \\
\hline $\begin{array}{l}\text { HOMA- } \\
\text { IR } \\
\text { index }\end{array}$ & 0.07 & 0.798 & 0.23 & 0.390 & -0.15 & 0.592 & 0.06 & 0.840 \\
\hline $\begin{array}{l}\text { Total } \\
\text { cholesterol }\end{array}$ & 0.03 & 0.911 & 0.11 & 0.692 & 0.35 & 0.183 & 0.42 & 0.133 \\
\hline $\begin{array}{l}\text { LDL } \\
\text { cholesterol }\end{array}$ & 0.11 & 0.688 & 0.15 & 0.588 & 0.26 & 0.325 & 0.47 & 0.091 \\
\hline $\begin{array}{l}\text { Ln(HDL } \\
\text { cholesterol) }\end{array}$ & 0.01 & 0.990 & -0.16 & 0.553 & 0.16 & 0.553 & -0.01 & 0.989 \\
\hline Ln(Triglycerid & de日),39 & 0.132 & 0.10 & 0.715 & -0.24 & 0.364 & -0.24 & 0.418 \\
\hline $\operatorname{Ln}(\mathrm{eGFR})$ & 0.37 & 0.155 & 0.17 & 0.541 & 0.13 & 0.644 & -0.18 & 0.530 \\
\hline $\begin{array}{l}\text { Prediabetes } \\
\text { sub- } \\
\text { group }\end{array}$ & $\begin{array}{l}\text { Prediabetes } \\
\text { sub- } \\
\text { group }\end{array}$ & $\begin{array}{l}\text { Prediabetes } \\
\text { sub- } \\
\text { group }\end{array}$ & $\begin{array}{l}\text { Prediabetes } \\
\text { sub- } \\
\text { group }\end{array}$ & $\begin{array}{l}\text { Prediabetes } \\
\text { sub- } \\
\text { group }\end{array}$ & $\begin{array}{l}\text { Prediabetes } \\
\text { sub- } \\
\text { group }\end{array}$ & $\begin{array}{l}\text { Prediabetes } \\
\text { sub- } \\
\text { group }\end{array}$ & & \\
\hline Age & -0.25 & 0.167 & 0.02 & 0.908 & -0.04 & 0.842 & 0.32 & 0.088 \\
\hline $\begin{array}{l}\text { Waist } \\
\text { circumference }\end{array}$ & 0.15 & 0.444 & 0.06 & 0.778 & 0.12 & 0.516 & -0.28 & 0.135 \\
\hline BMI & 0.01 & 0.961 & 0.07 & 0.706 & 0.16 & 0.386 & -0.25 & 0.180 \\
\hline $\operatorname{Ln}(\mathrm{HbA} 1 \mathrm{c})$ & -0.21 & 0.262 & 0.16 & 0.403 & 0.19 & 0.320 & 0.13 & 0.479 \\
\hline $\begin{array}{l}\text { Plasma } \\
\text { glucose } \\
\text { at } \\
\text { fasting }\end{array}$ & 0.30 & 0.100 & 0.15 & 0.418 & 0.18 & 0.328 & 0.06 & 0.774 \\
\hline $\begin{array}{l}\text { Plasma } \\
\text { glucose } \\
\text { postload }\end{array}$ & 0.18 & 0.358 & 0.20 & 0.314 & 0.18 & 0.341 & 0.05 & 0.800 \\
\hline $\begin{array}{l}\text { Insulin } \\
\text { at } \\
\text { fasting }\end{array}$ & 0.01 & 0.971 & 0.13 & 0.479 & -0.06 & 0.759 & -0.54 & 0.002 \\
\hline $\begin{array}{l}\text { Insulin } \\
\text { postload }\end{array}$ & 0.16 & 0.402 & 0.24 & 0.225 & 0.01 & 0.955 & -0.13 & 0.521 \\
\hline $\begin{array}{l}\text { HOMA- } \\
\text { IR } \\
\text { index }\end{array}$ & 0.03 & 0.879 & 0.15 & 0.441 & -0.04 & 0.821 & -0.52 & 0.004 \\
\hline $\begin{array}{l}\text { Total } \\
\text { cholesterol }\end{array}$ & 0.07 & 0.700 & -0.32 & 0.084 & 0.02 & 0.918 & 0.26 & 0.173 \\
\hline $\begin{array}{l}\text { LDL } \\
\text { cholesterol }\end{array}$ & 0.23 & 0.222 & -0.29 & 0.121 & 0.10 & 0.579 & 0.12 & 0.526 \\
\hline $\begin{array}{l}\text { Ln(HDL } \\
\text { cholesterol) }\end{array}$ & -0.20 & 0.294 & 0.07 & 0.714 & -0.10 & 0.586 & 0.38 & 0.038 \\
\hline Ln(Triglycerid & $\operatorname{les} 17$ & 0.351 & -0.18 & 0.350 & 0.14 & 0.439 & -0.21 & 0.263 \\
\hline
\end{tabular}




\begin{tabular}{|c|c|c|c|c|c|c|c|c|}
\hline $\begin{array}{l}\text { Parameter } \\
\text { Pearson } \\
\text { Correla- } \\
\text { tion }\end{array}$ & esRAGE & esRAGE & $\begin{array}{l}\text { Ln(serum } \\
\text { AGEs) }\end{array}$ & $\begin{array}{l}\text { Ln(serum } \\
\text { AGEs) }\end{array}$ & Ln(sRAGE) & Ln(sRAGE) & $\begin{array}{l}\text { Ln(tissue } \\
\text { AGEs) }\end{array}$ & $\begin{array}{l}\text { Ln(tiss } \\
\text { AGEs) }\end{array}$ \\
\hline$\overline{\operatorname{Ln}(\mathrm{eGFR})}$ & -0.33 & 0.077 & -0.25 & 0.191 & 0.03 & 0.878 & -0.13 & 0.496 \\
\hline
\end{tabular}

Supplemental table 2. Correlations between estimated metabolic parameters and sympathetic and parasympathetic activity.

\begin{tabular}{|c|c|c|c|c|c|c|}
\hline $\begin{array}{l}\text { Parameter } \\
\text { Pearson } \\
\text { Correlation }\end{array}$ & $\begin{array}{l}\text { LFa } \\
\text { component } \\
\text { variable }\end{array}$ & $\begin{array}{l}\mathrm{LFa} \\
\text { component } \\
\text { variable }\end{array}$ & $\begin{array}{l}\text { RFa } \\
\text { component } \\
\text { variable }\end{array}$ & $\begin{array}{l}\text { RFa } \\
\text { component } \\
\text { variable }\end{array}$ & $\begin{array}{l}\mathrm{LFa}+\mathrm{RFa} \\
\text { component } \\
\text { variable }\end{array}$ & $\begin{array}{l}\text { LFa+RFa } \\
\text { component } \\
\text { variable }\end{array}$ \\
\hline & $\mathbf{r}$ & $\mathrm{p}$ & $\mathbf{r}$ & $\mathbf{p}$ & $\mathbf{r}$ & $\mathbf{p}$ \\
\hline $\begin{array}{l}\text { Whole } \\
\text { cohort }\end{array}$ & $\begin{array}{l}\text { Whole } \\
\text { cohort }\end{array}$ & $\begin{array}{l}\text { Whole } \\
\text { cohort }\end{array}$ & $\begin{array}{l}\text { Whole } \\
\text { cohort }\end{array}$ & $\begin{array}{l}\text { Whole } \\
\text { cohort }\end{array}$ & $\begin{array}{l}\text { Whole } \\
\text { cohort }\end{array}$ & $\begin{array}{l}\text { Whole } \\
\text { cohort }\end{array}$ \\
\hline Age & -0.30 & 0.050 & -0.43 & 0.004 & -0.6 & 0.012 \\
\hline $\begin{array}{l}\text { Waist } \\
\text { circumference }\end{array}$ & -0.15 & 0.336 & -0.15 & 0.325 & -0.15 & 0.326 \\
\hline BMI & -0.19 & 0.214 & -0.20 & 0.198 & -0.20 & 0.166 \\
\hline $\operatorname{Ln}(\mathrm{HbA} 1 \mathrm{c})$ & -0.22 & 0.152 & -0.33 & 0.028 & -0.23 & 0.125 \\
\hline $\begin{array}{l}\text { Plasma } \\
\text { glucose at } \\
\text { fasting }\end{array}$ & -0.07 & 0.664 & -0.15 & 0.321 & -0.18 & 0.123 \\
\hline $\begin{array}{l}\text { Plasma } \\
\text { glucose } \\
\text { postload }\end{array}$ & -0.13 & 0.404 & -0.08 & 0.595 & -0.07 & 0.654 \\
\hline $\begin{array}{l}\text { Ln(Insulin } \\
\text { at fasting) }\end{array}$ & -0.29 & 0.062 & -0.18 & 0.261 & -0.24 & 0.110 \\
\hline $\begin{array}{l}\text { Ln(Insulin } \\
\text { postload) }\end{array}$ & -0.24 & 0.132 & -0.13 & 0.420 & -0.19 & 0.206 \\
\hline $\begin{array}{l}\text { HOMA-IR } \\
\text { index }\end{array}$ & -0.28 & 0.066 & -0.19 & 0.234 & -0.25 & 0.091 \\
\hline $\begin{array}{l}\text { Total } \\
\text { cholesterol }\end{array}$ & -0.21 & 0.164 & -0.19 & 0.212 & -0.25 & 0.088 \\
\hline $\begin{array}{l}\text { LDL } \\
\text { cholesterol }\end{array}$ & -0.17 & 0.279 & -0.19 & 0.220 & -0.26 & 0.077 \\
\hline $\begin{array}{l}\text { Ln(HDL } \\
\text { cholesterol) }\end{array}$ & 0.01 & 0.953 & 0.13 & 0.405 & 0.09 & 0.532 \\
\hline Ln(Triglycerides) & 0.05 & 0.752 & 0.06 & 0.723 & 0.02 & 0.919 \\
\hline Ln(eGFR) & -0.03 & 0.860 & 0.10 & 0.540 & 0.13 & 0.402 \\
\hline $\begin{array}{l}\text { NGT } \\
\text { subgroup }\end{array}$ & $\begin{array}{l}\text { NGT } \\
\text { subgroup }\end{array}$ & $\begin{array}{l}\text { NGT } \\
\text { subgroup }\end{array}$ & $\begin{array}{l}\text { NGT } \\
\text { subgroup }\end{array}$ & $\begin{array}{l}\text { NGT } \\
\text { subgroup }\end{array}$ & $\begin{array}{l}\text { NGT } \\
\text { subgroup }\end{array}$ & $\begin{array}{l}\text { NGT } \\
\text { subgroup }\end{array}$ \\
\hline Age & -0.61 & 0.016 & -0.62 & 0.013 & -0.40 & 0.126 \\
\hline $\begin{array}{l}\text { Waist } \\
\text { circumference }\end{array}$ & -0.34 & 0.218 & -0.24 & 0.389 & -0.04 & 0.886 \\
\hline BMI & -0.36 & 0.186 & -0.33 & 0.231 & -0.24 & 0.377 \\
\hline $\operatorname{Ln}(\mathrm{HbA} 1 \mathrm{c})$ & -0.12 & 0.677 & -0.26 & 0.352 & -0.07 & 0.802 \\
\hline $\begin{array}{l}\text { Plasma } \\
\text { glucose at } \\
\text { fasting }\end{array}$ & -0.32 & 0.246 & -0.40 & 0.142 & -0.17 & 0.543 \\
\hline
\end{tabular}




\begin{tabular}{|c|c|c|c|c|c|c|}
\hline $\begin{array}{l}\text { Parameter } \\
\text { Pearson } \\
\text { Correlation }\end{array}$ & $\begin{array}{l}\text { LFa } \\
\text { component } \\
\text { variable }\end{array}$ & $\begin{array}{l}\text { LFa } \\
\text { component } \\
\text { variable }\end{array}$ & $\begin{array}{l}\text { RFa } \\
\text { component } \\
\text { variable }\end{array}$ & $\begin{array}{l}\text { RFa } \\
\text { component } \\
\text { variable }\end{array}$ & $\begin{array}{l}\mathrm{LFa}+\mathrm{RFa} \\
\text { component } \\
\text { variable }\end{array}$ & $\begin{array}{l}\mathrm{LFa}+\mathrm{RFa} \\
\text { component } \\
\text { variable }\end{array}$ \\
\hline $\begin{array}{l}\text { Plasma } \\
\text { glucose } \\
\text { postload }\end{array}$ & -0.02 & 0.953 & -0.16 & 0.559 & -0.18 & 0.509 \\
\hline $\begin{array}{l}\text { Insulin at } \\
\text { fasting }\end{array}$ & -0.37 & 0.176 & -0.07 & 0.802 & -0.17 & 0.538 \\
\hline $\begin{array}{l}\text { Insulin } \\
\text { postload }\end{array}$ & -0.29 & 0.299 & -0.01 & 0.992 & -0.18 & 0.517 \\
\hline $\begin{array}{l}\text { HOMA-IR } \\
\text { index }\end{array}$ & -0.41 & 0.130 & -0.11 & 0.704 & -0.20 & 0.461 \\
\hline $\begin{array}{l}\text { Total } \\
\text { cholesterol }\end{array}$ & -0.08 & 0.771 & -0.04 & 0.897 & -0.21 & 0.438 \\
\hline $\begin{array}{l}\text { LDL } \\
\text { cholesterol }\end{array}$ & -0.09 & 0.743 & -0.07 & 0.800 & -0.30 & 0.255 \\
\hline $\begin{array}{l}\text { Ln(HDL } \\
\text { cholesterol) }\end{array}$ & 0.27 & 0.338 & 0.02 & 0.935 & 0.05 & 0.866 \\
\hline Ln(Triglycerides) & -0.29 & 0.289 & -0.33 & 0.231 & -0.33 & 0.214 \\
\hline Ln(eGFR) & 0.50 & 0.059 & 0.66 & 0.008 & 0.54 & 0.030 \\
\hline $\begin{array}{l}\text { Prediabetes } \\
\text { subgroup }\end{array}$ & $\begin{array}{l}\text { Prediabetes } \\
\text { subgroup }\end{array}$ & $\begin{array}{l}\text { Prediabetes } \\
\text { subgroup }\end{array}$ & $\begin{array}{l}\text { Prediabetes } \\
\text { subgroup }\end{array}$ & $\begin{array}{l}\text { Prediabetes } \\
\text { subgroup }\end{array}$ & $\begin{array}{l}\text { Prediabetes } \\
\text { subgroup }\end{array}$ & $\begin{array}{l}\text { Prediabetes } \\
\text { subgroup }\end{array}$ \\
\hline Age & -0.13 & 0.496 & -0.33 & 0.078 & -0.22 & 0.220 \\
\hline $\begin{array}{l}\text { Waist } \\
\text { circumference }\end{array}$ & -0.01 & 0.973 & -0.02 & 0.921 & -0.01 & 0.998 \\
\hline BMI & -0.04 & 0.854 & -0.05 & 0.782 & -0.05 & 0.800 \\
\hline $\operatorname{Ln}(\mathrm{HbA} 1 \mathrm{c})$ & -0.22 & 0.258 & -0.33 & 0.085 & -0.20 & 0.266 \\
\hline $\begin{array}{l}\text { Plasma } \\
\text { glucose at } \\
\text { fasting }\end{array}$ & -0.20 & 0.299 & -0.07 & 0.718 & -0.10 & 0.571 \\
\hline $\begin{array}{l}\text { Plasma } \\
\text { glucose } \\
\text { postload }\end{array}$ & -0.10 & 0.624 & -0.08 & 0.691 & -0.02 & 0.912 \\
\hline $\begin{array}{l}\text { Insulin at } \\
\text { fasting }\end{array}$ & -0.21 & 0.289 & -0.15 & 0.457 & -0.14 & 0.442 \\
\hline $\begin{array}{l}\text { Insulin } \\
\text { postload }\end{array}$ & -0.19 & 0.354 & -0.15 & 0.477 & -0.13 & 0.493 \\
\hline $\begin{array}{l}\text { HOMA-IR } \\
\text { index }\end{array}$ & -0.18 & 0.366 & -0.13 & 0.499 & -0.13 & 0.498 \\
\hline $\begin{array}{l}\text { Total } \\
\text { cholesterol }\end{array}$ & -0.41 & 0.028 & -0.36 & 0.056 & -0.37 & 0.035 \\
\hline $\begin{array}{l}\text { LDL } \\
\text { cholesterol }\end{array}$ & -0.37 & 0.050 & -0.32 & 0.092 & -0.34 & 0.057 \\
\hline $\begin{array}{l}\text { Ln(HDL } \\
\text { cholesterol) }\end{array}$ & 0.14 & 0.464 & 0.25 & 0.188 & 0.24 & 0.182 \\
\hline Ln(Triglycerides) & 0.34 & 0.071 & -0.38 & 0.041 & -0.36 & 0.045 \\
\hline Ln(eGFR) & 0.25 & 0.190 & 0.14 & 0.463 & 0.12 & 0.530 \\
\hline
\end{tabular}




\begin{tabular}{|c|c|c|c|c|c|c|}
\hline $\begin{array}{l}\text { Parameter } \\
\text { Pearson } \\
\text { Correlation }\end{array}$ & $\begin{array}{l}\text { LFa } \\
\text { component } \\
\text { variable }\end{array}$ & $\begin{array}{l}\text { LFa } \\
\text { component } \\
\text { variable }\end{array}$ & $\begin{array}{l}\text { RFa } \\
\text { component } \\
\text { variable }\end{array}$ & $\begin{array}{l}\text { RFa } \\
\text { component } \\
\text { variable }\end{array}$ & $\begin{array}{l}\text { LFa+RFa } \\
\text { component } \\
\text { variable }\end{array}$ & $\begin{array}{l}\text { LFa+RFa } \\
\text { component } \\
\text { variable }\end{array}$ \\
\hline $\mathrm{LFa}-$ & $\mathrm{LFa}-$ & $\mathrm{LFa}-$ & $\mathrm{LFa}-$ & $\mathrm{LFa}-$ & $\mathrm{LFa}-$ & $\mathrm{LFa}-$ \\
\hline sympathetic & sympathetic & sympathetic & sympathetic & sympathetic & sympathetic & sympathetic \\
\hline nervous & nervous & nervous & nervous & nervous & nervous & nervous \\
\hline system & system & system & system & system & system & system \\
\hline activity; & activity; & activity; & activity; & activity; & activity; & activity; \\
\hline $\mathrm{RFa}-$ & $\mathrm{RFa}-$ & $\mathrm{RFa}-$ & $\mathrm{RFa}-$ & $\mathrm{RFa}-$ & $\mathrm{RFa}-$ & $\mathrm{RFa}-$ \\
\hline $\begin{array}{l}\text { parasympa- } \\
\text { thetic }\end{array}$ & $\begin{array}{l}\text { parasympa- } \\
\text { thetic }\end{array}$ & $\begin{array}{l}\text { parasympa- } \\
\text { thetic }\end{array}$ & $\begin{array}{l}\text { parasympa- } \\
\text { thetic }\end{array}$ & $\begin{array}{l}\text { parasympa- } \\
\text { thetic }\end{array}$ & $\begin{array}{l}\text { parasympa- } \\
\text { thetic }\end{array}$ & $\begin{array}{l}\text { parasympa- } \\
\text { thetic }\end{array}$ \\
\hline nervous & nervous & nervous & nervous & nervous & nervous & nervous \\
\hline system & system & system & system & system & system & system \\
\hline activity & activity & activity & activity & activity & activity & activity \\
\hline
\end{tabular}

\section{Hosted file}

Table 1.docx available at https://authorea.com/users/422915/articles/528508-the-relationshipbetween-endogenous-secretory-rage-and-cardiac-autonomic-function-in-prediabetes

\section{Hosted file}

Table 2.docx available at https://authorea.com/users/422915/articles/528508-the-relationshipbetween-endogenous-secretory-rage-and-cardiac-autonomic-function-in-prediabetes

\section{Hosted file}

Table 3.docx available at https://authorea.com/users/422915/articles/528508-the-relationshipbetween-endogenous-secretory-rage-and-cardiac-autonomic-function-in-prediabetes 